\title{
ANALYSIS OF ACCOUNTING INFORMATION TOWARDS STOCK RETURN IN FOOD AND BEVERAGE INDUSTRY LISTED ON INDONESIA STOCK EXCHANGE FOR THE PERIOD OF 2010-2014
}

\section{Meidisa Joane}

Swiss German University, Tangerang, Indonesia Email : meidisajoane@hotmail.com

\section{Indra Pratama}

Swiss German University, Tangerang, Indonesia Email : pratama.indra@icloud.com

This study investigates the correlation of the accounting information: current ratio, debt-to-equity ratio, total asset turnover, price-to-earnings ratio, and firm size towards stock return. This is to respond the economic condition and improvement of Asian market towards the global economy, and the increasing consumer spending in food and beverage in Indonesia. Some previous studies found that there is a correlation between the variables and the stock return. This study then reveals a significant correlation of current ratio, debt-to-equity ratio, total asset turnover, and firm size when they are put as a single variable, towards the stock return. However, the price-to-earnings ratio is found to have an insignificant correlation towards the stock return, and so do all the accounting information as independent variables when combined in multiple regression model.

Accounting information, ratio, stock return, food and beverage

industry, multiple regression model 


\section{INTRODUCTION}

I t grabs a singular attention when discussing about the market condition at the present time, especially when it comes to the Asian market. According to Tamaki, Asian regions have shown an impressive survival throughout the financial crisis which happened in 1997/98, and proved to maintain its economy back to a stable movement. On that basis, it is believed that those regions will have a major growth and improvement in global economy for the following year (Tamaki, 2013).

This condition must attract investors to think about investing in Asian industries, considering it is crucial for them to have a guarantee that there will be equitable investment return even if there are risks existing.

The food and beverage industry in Indonesia, based on a study by McKinsey, is one which has been predicted to have a rapid growth in its annual consumer spending from USD 73 billion in 2011 to USD 194 billion in 2030. This is due to the sizable population of people living in Indonesia, a rise in income, and a modern lifestyle that requires a major consumption for food and beverage (Damayanti, 2013).

A study done by economic researchers from United States of America tells that following the crisis in the late 1990s, the food consumption patterns of Indonesian people have altered since then. The consumption of dairy and meat have grown while the consumption of grain have fallen. This is in harmony with the global pattern which shows a high consumption in meats, dairy products, and sugar. Due to the huge amount of population in Indonesia, or as the 4th world's most populous state, there is a prediction that there is relationship between the food consumption and the sales, trade, or investment. This is supported by the fact that urbanization and the rise in household income have been the causes of the consumptive behaviour the people have. The lifestyle of urbans have caused the sales of modern food retailers rose from US $\$ 1.5$ billion in 1999 to over US\$5.6 billion in 2009, and the share of total retail food sales grew from $5 \%$ to $11 \%$ during that period (Dyck, Woolverton, \& Rangkuti, 2012).

The Indonesia Investment Coordination Board, or "Badan Koordinasi Penanaman Modal" (BKPM) in their report about investing in Indonesia's food and beverage industry shows potential because there is a growth in middle class and spending on food and beverage products, abundant agricultural resources and increasing levels of production in key products (palm oil, cocoa, livestock, etc.), track record of rapidly increasing Foreign Direct Investment (FDI) in food and beverage manufacturing by $400 \%$ since 2010, the growing workforce up to almost 1 million in medium and large-size of food and beverage manufacturing, and Indonesia has the lowest operating costs of food and beverage manufacturing plant in ASEAN-5 (BKPM, 2014). Hence, the author thinks that food and beverage sector in Indonesia is an appropriate sample for the analysis.

In relation with the information provided about the industry, there are five (5) food and beverage companies listed on the Indonesia Stock Exchange (IDX) that potentially have requirements to be analyzed through its total return. Accounting information provided by these companies play a significant role in its valuation, considering there are a combination of multiple indicators within which investors' decisions are genuinely 
determined.

This information is presented in the company financial statements. Financial statement, as known, is basically a tool that investors use to see through a company whether or not it is profitable, in order to select stocks. It supports the findings that exclaimed the full reliability of investors is on the accounting information provided by the financial statements available in public, and it is applicable to all types of companies (Mohanram 2005), (Tantipanichkul \& Supattarakul, 2011). The author would like to investigate specifically the accounting information to discover its rightfulness in predicting stock return and therefore has chosen it as the variable to be analysed in this thesis.

This study is basically aimed to analyze the correlation between accounting information and the stock return of the listed food and beverage companies on IDX for period 2010-2014, to examine what kind of correlation the 4 determinant variables (current ratio (CR), debt-toequity ratio (DER), total asset turnover (TATO), price-to-earnings ratio $(\mathrm{P} / \mathrm{E})$, and firm size) have with the stock return, to evaluate the significance of each variable, in relation to the stock return, to find the result whether or not the accounting information used in this study will have the same correlation on stock return, as studies done by previous researchers, and to contribute to other researches that this study of analysis of accounting information towards stock return in food and beverage companies represents the Indonesia's relatively stock market trend in a specific sector.

\section{LITERATURE REVIEW II.I. Basics Of Financial Statements}

Financial statements are the activity of capturing and reporting a company's business activities prepared by the the company itself to outside parties (Drake \& Fabozzi, 2012).

IAS 1 clarifies that "financial statements are a structured representation of the financial position and financial performance of an entity. The objective of financial statements is to provide information about the financial position, financial performance and cash flows of an entity that is useful to a wide range of users in making economic decisions. Financial statements also show the results of the management's stewardship of the resources entrusted to it. To meet this objective, financial statements provide information about an entity's assets, liabilities, income, and expenses (including gains and losses), contributions by and distributions to owners in their capacity as owners and cash flows. This information along with other information in the notes, assists users of financial statements in predicting the entity's future cash flows and in particular, their timing and certainty" (IAS, 2011).

In brief, financial statements are the tools to project a firm's overall performance which is represented by specific accounts in which it is combined can provide some information that users need.

\section{II.II. Accounting Information}

Accounting information is divided into 2 categories: Management and Financial Accounting. Management, containing data regarding costs and budget which is useful for internal users such as management. Financial, providing accounts that are useful for external users such as stockholders, potential stockholders, creditors, and government agencies. The accounting information records and summarizes the company's financial 
activities. Since the investors' rewards or losses count fully on those activities, so the presented information on the financial statements are crucial (Zhang, 2013). The instrumental variables approach using accounting ratios were empirically found to give better predictions in the capital market than the personal judgments or forecasts (Bühler, Hax, \& Schmidt, 2012). In conclusion, it is confirmed that accounting information is considered as one essential tool to help the investors make decisions. From such characteristic, the use of accounting information is optimum in financial accounting, which deals a lot with external users. Accounting information must also follow some qualitative requirements in order to be valid.

\section{II.III. Financial Statement Analysis}

In order to evaluate all the provided information from all time and for forecasting purposes, analysis need to be performed. Financial statement analysis is one of most valuable technique used to predict risk and potential returns through the available accounting information. According to Subramanyam and Wild, financial statement analysis is an application of analytical tools and methods that create estimation and evaluation, in order to reduce uncertainty and selfjudgment in business analysis that involves the analysis of accounting, financial, and prospective. Financial statements can be analyzed by using 3 types of analysis: horizontal, vertical, and ratio (Weygandt, Kimmel, \& Kieso, 2010). To sum up, financial statements have been having similar functions over the time, which emphasizes an instrument performed by numerous kinds of users from different areas. The purpose is to fulfil their need in having a more detailed insight, especially about a business' financial health and other ongoing possibilities.

\section{II.IV. Ratio Analysis}

Ratio analysis is the most common tools used by users to forecast the future economic benefits of a company. This corresponds to the intention of more advanced investigation of selected sections or areas. As stated by Subramanyam and Wild, there are internal and external activities that affect a firm's ratios. Internal, involving the internal control, corporate governance, monitoring, and management system, in which if they are less dependable, then the outcoming ratios are also less dependable. External factors such as economic conditions, industrial matters, and applied standards do also have impact on the way a company discloses its information which indirectly the outcoming ratios. According to the most recent literature, the computation of key financial ratios are categorized into 5 different areas: Liquidity, Leverage, Asset Utilization, Profitability, and Market Price (Bodie, Kane, \& Marcus, 2013). To summarize, ratio analysis is used to estimate firm's future performance, compare data internally and externally, and it always alters depending on the current condition.

\section{II.IV.I Liquidity Ratio}

Liquidity analysis is basically used to measure the ability of a company to pay its short-term liabilities and how able it is when faced with urgent call for cash. The higher the number, the more it is able to cover its obligations (Weygandt, Kimmel, $\&$ Kieso, 2010). Liquidity ratios determine whether the resources available on hand are able to meet short-term cash needs, which are influenced by cash inflows and outflows during the period (Wild, Shaw, \& Chiapetta, 2012). 
Current ratio is one that is included in liquidity ratios that will be used as an instrument in this study. This ratio indicates the ability of a company to fulfil its current liabilities with its current assets (Drake \& Fabozzi, 2010). The purpose of current ratio is to show how well a company could cover its debts if it had to. Thus, a company desires a current ratio over 1.0 because this number means that the company could pay off all the obligations using assets available on hand (Drake \& Dingler, 2001).

In brief, liquidity ratios which contain current ratio, measures company's ability of paying liabilities using current assets in urgent conditions.

The value of current ratio will be generated from the total of current assets divided by current liabilities.

Current Ratio $=($ Current Assets $) /($ Current Liabilities)

\section{II.IV.II. Leverage Ratio}

Leverage ratios address the firm's feasibility in a long-term run to cover its long-term liabilities, which are affected by its operating, financing, and investing activities (Larson, Wild, \& Chiappetta, 2013). Leverage ratios are usually used by creditors to find out whether the company is able to repay its debts to the degree of the company make use of the borrowed money and how the risks are getting in the way (Poznanski, Sadownik, \& Gannitsos, 2013).

Debt-to-equity will be measured within this study. This ratio presents the company's capital structure and whether the company is more reliant on borrowings (debt) or shareholder's equity to finance its assets and liabilities (D'Amato, 2010). Debt-to-equity ratio also pictures the portion owned by the owners and the portion owned by the creditors (Tyson \& Schell, 2008). The smaller the amount of ratio is better because it means the debt is less than equity. The amount less than 0.5 is preferable (Drake \& Dingler, 2001).

To sum up, leverage ratio, related to debtto-equity ratio, suggests the total debts that can be covered by equity, which is another from assets. The debt-to-equity ratio is computed from dividing total liabilities by the total stockholders' equity.

Debt-to-Equity Ratio=(Total Liabilities $) /$ (Total Equity)

\section{II.IV.III. Asset Utilization (Activity, or Efficiency, or Turnover) Ratio}

Asset utilization ratio, or also known as efficiency, or activity, or turnover ratio, is an instrument used to measure the utilization of any type of assets that produce money out of it (Bodie, Kane, \& Marcus, 2013). Asset utilization ratios specify how efficiently or intensively a company manages its assets to create revenue (Ross, Westerfield, \& Jordan, 2010).

Asset turnover ratio is one of activity ratios used to show how hard the firm's assets are working and how well it leads to generating revenue in form of sales, which will be used in this study (Brealey, Myers, \& Allen, 2011). Asset turnover rate measures how efficiently company's capital is being used and how it can generate income. A higher percentage of total asset turnover shows the more stronger the company's business is. A rate of $45 \%-50 \%$ or higher means the company is in its strong condition, while a rate less than $30 \%-35 \%$ means that it needs to reduce expenses and grows production (Kantrovich, 2011).

Concisely, asset utilization ratio, such as 
total asset turnover ratio, is used to find out how assets are well-used to create revenue of a business.

The formula for asset turnover ratio is: total sales divided by average total assets.

Asset Turnover Ratio $=($ Total Sales $) /$ (Average Total Assets)

(3)

\section{II.IV.IV. Market Price Ratio}

Market price ratio in general assesses the growth opportunities and the result of overall operations of a company in terms of a share of stock (Bodie, Kane, \& Marcus, 2013).

Market price ratio or also known as valuation ratio, is a tool to compare the cost of a purchased stock against the profit earned. The aim of this is to see whether the invested money would be beneficial (Pietersz, 2005-2013).

One of the market price ratios used in this study is price to earnings ratio $(\mathrm{P} / \mathrm{E})$. $\mathrm{P} / \mathrm{E}$ is sometimes used by investors to evaluate the company's ability to generate future cash flow (Drake \& Fabozzi, 2010). The $\mathrm{P} / \mathrm{E}$ ratio points out the investors' expectations about the future performance of a company. A result of 10 or less usually shows that the investors expect the earnings to decrease from the current level or an undervaluation of shares. (Williams, et al., 2011).

To conclude, a market price ratio like $\mathrm{P} / \mathrm{E}$ ratio is used to forecast and evaluate company's future income investors can earn.

$\mathrm{P} / \mathrm{E}$ is measured from dividing the share price by the earnings per share of the company for that period.

Price-to-Earnings $\quad$ Ratio $=($ Price $\quad$ per
Share)/(Earnings per Share)

(4)

\section{II.V. Firm Size}

There have been studies about the importance of adding control variables in determining the stock returns. Firm size happened to be most popular variable used and empirically found to have a relationship with stock returns, since it represents one of company's characteristics (Amir, 2011). This study supports the result found by Leledakis, Davidson, and Smith in observing the role of firm size in predicting stock return in London Stock Exchange. In their findings, the firm size which is measured by total assets (TA) did have effects on stock return. Smaller companies with high leverage level generated a higher return than the bigger ones. The level of impact was increasing as the leverage also increased (Leledakis, Davidson, \& Smith, 2004).

Derived from those findings, the author summarizes that firm size significantly affects the stock return, since it reflects the volatility and the activity of company based on the category of the total assets it is having. Hence, based on prior studies, the author adds firm size as a determinant in predicting stock return.

\section{II.VI. Stock}

From the company point of view, stock is a symbol of ownership share owned by a company. The performance of this ownership is determined by its success and its real assets (Bodie, Kane, \& Marcus, 2013). Although stocks principally embody some degree of company's ownership, they are still divided into 2 types: First, common stock, which shareholders can yield from the 
dividends paid and it grants them to have the voting rights. Secondly, the preferred stock, has the same function as common stock except it eliminates the voting rights unlike the common shareholders have. In spite of that, their dividends are paid earlier than for the common shareholders, and can be called back at any time of period (Emerald, 2015).

\section{II.VI.I. Stock Return}

Generally, stocks are hoped to create more wealth for the investors in the upcoming time. Stock return is an essential tool to measure the company performance and financial health (Folger, 2014). A return, according to Ross, Westerfield, and Jordan, is any gain or loss earned once an investor invested money in a company by purchasing its assets. The total return of a stock contains 2 elements: dividend income and capital gain. This is known as dividend growth model (Ross, Westerfield, \& Jordan, 2010). The formula is:

Total Dollar Return=Dividend Income+Capital Gain

The first component, dividend income, is calculated by dividing the expected cash dividend with the current price.

Dividend Income $=\mathrm{D} 1 / \mathrm{P} 0$

The second component, capital gain, is computed as the change in stock price during the year divided by the price from the prior year.

Capital Gain $=(\mathrm{P} 1-\mathrm{P} 0) / \mathrm{P} 0$

In summary, total stock return is the amount of money that is earned or sacrificed by investors as a reward or punishment of investing their money in a specific business.

\section{II.VII. Dividend}

Dividend is a sum of money paid to the owners as a substantial of the company income. It can be given in the form of either cash or stock (Ross, Westerfield, \& Jordan, 2010). The decision of dividend payment is determined by the board of management and relies on the company recent earnings (Frank, Bernanke, Gan, \& Kang, 2009).

To conclude, dividend is the total money paid regularly in a period based on management's agreement, in form of cash or shares, taken out of and are subject to company's income, and are recognized as a return for the investors.

\section{II.8. Food and Beverage Industry}

As the population in the world keep increasing, the demand for more food also rapidly rocketed $\neg$. Different types of foods were also on major request (Latham, 2000).

A study from Gerbens-Leenes, Nonhebel, and Krol reported that there is a relationship between annual per capita and the composition of food consumption patterns (Gerbens-Leenes, Nonhebel, \& Krol, 2010).

The food prices are volatile in a short-term run. The influencing factors behind this are natural phenomenon, such as weather conditions, unpleasant condition of living being, changes in oil prices (affecting agriculturral production costs), new demands (especially for biofuels) and the "guessing" habit of people (Warr, 2011).

II.9. Summary of Previous Studies 
Hasintongan in his research, found that current ratio is positively related to the stock return. Debt-to-equity ratio in contrast, was found to have a negative and significant correlation with stock return. The asset turnover ratio is negativeand significantly correlated with the stock return. Price-to-earnings ratio has a negative relationship with the stock return. Firm size was shown to have a positive correlation towards stock return (Hasintongan, 2010).

Another finding showed a positive, significant relationship between TATO, financial leverage (FL), and stock return. Current ratio (CR), however, happened to have a negative relationship. It was believe that it was caused by the poor performance of Tehran Stock Exchange in disclosing financial information during the period of 2006-2010 (Babaei, Babaei, Abdi, \& Rezaei, 2014).

On the contrary, Martani, Mulyono, and Khairurizka documented that there is a positive correlation between DER and stock return and a negative relationship between CR, TATO, and firm size altogether with the stock return. A high DER in this case stood for an aggressive use of debt financing. TATO, on the other hand, was negatively correlated with the stock return because the domination of big companies on high stock return that complicatedly obstructed the TATO to increase and also because there was in influence caused by non operating profit which was not earned from sales. The firm size correlated positively with stock return, which was expected to be influenced by risk diversification, dominant market position, and a better access to capital market (Martani, Mulyono, \& Khairurizka, 2009).

Another study observed by Er and Vuran showed a positive impact of firm size on stock return. This was described by the fact that big firms in Turkey appeared to be more profitable than the small ones. Likewise, the turnover ratios significantly affected the stock return. This showed the higher operational performance of the companies. A different way happened to the debt management ratios which included $\mathrm{D} / \mathrm{E}$ ratio, that showed a negative relationship with the stock return. The reason of this was the inadequate opportunity of a long-term borrowing and short-term financing of fixed assets in Turkish market that forced them to invest more in companies who pay dividends to get an immediate return (Er \& Vuran, 2012).

In a research done by Ghasempour and Ghasempour, there were indications that all fundamental variables-Return On Assets (ROA), Changes in ROA, Changes in Net Profit Margin (NPM), Changes in Total Asset Turnover (TATO), and Operating Cashflow-have a strong significant relationship with the stock return even though no relationship was found between the cash flow ratio (liquidity) and stock return and there was an insignificant correlation between operating leverage and stock return (Ghasempour \& Ghasempour, 2013).

Theoretical Framework

This study contains 2 main variables: accounting information and stock return. Accounting information, to be more specific, diversifies into 5 independent variables, which are current ratio, debtto-equity ratio, total asset turnover, priceto-earnings ratio, and firm size. On the opposite, the dependent variable here is the stock return, which is formulated from 3 determinants, which are stock price from current year and prior year, and dividends paid. 


\section{METHODOLOGY}

\section{III.I. Research Design}

The data were gathered from the audited financial statements from Indonesia Stock Exchange (IDX) (www.idx.co.id) website and the companies' own websites. The stock prices were collected from the Yahoo! Finance (www.finance.yahoo. com). This is an exploratory study, and the hypothesis testing and analysis use T-Test, F-Test, Pearson Correlation, and multiple regression. The time frame is 5 years (2010-2014), and the final sample is 5 companies in food and beverage sector listed on IDX.

\section{Research Questions}

Question \#1: Is there any correlation between current ratio and stock return?

Question \#2: Is there any correlation between debt-to-equity ratio and stock return?

Question \#3: Is there any correlation between total asset turnover and stock return?

Question \#4: Is there any correlation between price-to-earnings ratio and stock return?

Question \#5: Is there any correlation between firm size and stock return?

Research Hypotheses

Hypothesis 1.1: There is a significant correlation between current ratio \& stock return

Hypothesis 2.1: There is a significant correlation between debt-toequity ratio \& stock return
Hypothesis 3.1: There is a significant correlation between total asset turnover \& stock return

Hypothesis 4.1: There is a significant correlation between price-toearnings ratio \& stock return

Hypothesis 5.1: There is a significant correlation between firm size \& stock return

Research Model

Stock Return $=\mathrm{a}+$ b1CurrentRatio + b2Debt-to-equityRatio +

b3TotalAssetTurnoverRatio + b4Price-toEarningsRatio + b5FirmSize

\section{RESULTS AND DISCUS- SIONS}

Classical assumption test have been done as the initial step to ensure that the selected data fulfil the requirements of the analysis.

\section{IV.I. Hypotheses Testing Hypothesis 1.1: There is a significant correlation between current ratio and stock return.}

The hypothesis regarding one-on-one correlation between the 2 variables is tested using paired samples correlation, model summary adjusted $\mathrm{R}$ square, and the two-tailed paired sample T-Test in SPSS software.

The result of paired samples correlations is $-8.2 \%$ which indicates a negative correlation. The strength of the correlation is then described by the adjusted $\mathrm{R}$ square of $-3.6 \%$. The amount of below $10 \%$ represents a trivial or very weak correlation. However, the t value in Paired Samples Test points out an amount of 
4.573 which is out of the lower and upper bounds of 1.01312 and 2.67968 , meaning that the correlation between the variables is significant.

The supporting business analysis regarding the statistical result is the increase or decrease of current assets and current liabilities that the all 5 companies have that determine the fluctuation of current ratio. The explaining factors behind the decrease of current ratio over the years while the stock return keeps increasing are the higher account payables, trust receipts payables related with the importing activities, the short-term debt including current maturities, working capital loan, and the decreasing amount of assets that the 5 companies experienced.

\section{Hypothesis 2.1: There is a significant correlation between debt-to-equity ratio and stock return.}

The results from statistics are a positive correlation of $32.1 \%$ and strength of $6.4 \%$ which is explained by the adjusted $\mathrm{R}$ square, indicating a very small correlation between the variables. The t value in Paired Samples Test is nevertheless 1.055 which is outside the range of $-0.22665-0.70105$, signifying a significant correlation.

One of the business reasons that supports the positive and significant correlation between DER and stock return is the fact that the increase in current liabilities as discussed in Hypothesis 1.1 does have an impact on the increase of total liabilities for this hypothesis, which involves the increase in tax payable on account of higher taxable income and increase in net value-added tax (VAT) payable. In addition, there is also an increase in noncurrent liabilities caused by a higher long-term debt net of current maturities to finance capacity expansion, advances for stock subscription, additional debt to finance new investments, for technical improvements and production efficiency, for raw materials purchases and also production supplies.

\section{Hypothesis 3.1: There is a significant correlation between total asset turnover and stock return.}

The correlation here is positive with the amount of $23.7 \%$. The coefficient of strength is categorized as a very weak one, embodied by the adjusted $\mathrm{R}$ square of $1.5 \%$. A significant correlation lies between the variables from the presentation of $t$ value being in the outer surface of bounds.

The findings justify the economical facts regarding the increasing volume of domestic sales, extensive distribution, launching of new packaging designs for its products, respond to inflation and the weakening value of Indonesian Rupiah that occured during 2013 which leads to increasing price of products, improved revenue management, and exporting activities for business expansion, which contribute a lot in the rising amount of total sales, causing the TATO to escalate over the time.

\section{Hypothesis 4.1: There is a significant correlation between price-to-earnings ratio and stock return.}

Derived from the results above, the $\mathrm{P} / \mathrm{E}$ and stock return have a negative correlation amounted to $-11.8 \%$ using the Paired Samples Correlations. It is asserted that it is a very weak correlation from the coefficient of $-2.9 \%$ in adjusted $\mathrm{R}$ square. The significance is determined from the fact that the $t$ value is inside the upper and lower bounds, meaning that it 
is insignificant.

In general, the results of $\mathrm{P} / \mathrm{E}$ of all 5 companies from author's own calculation are almost the same of between $10-30$ times of earnings which is the standard and fair valuation in the market. However, since $\mathrm{P} / \mathrm{E}$ ratio is used to compare between companies in the same industries and in this thesis showing that overall results are almost equal, meaning that the value of stocks from each company is almost the same. The share prices of 5 companies (DLTA, ICBP, INDF, MLBI, and MYOR), on the other hand, always show the same upward trend for the last 5 years 2010 until 2014, despite of the local currency and inflation issues that are getting in the way. Thus, it makes the $\mathrm{P} / \mathrm{E}$ is insignificant towards the stock return.

\section{Hypothesis 5.1: There is a significant correlation between firm size and stock return.}

The firm size and stock return are negatively correlated for its correlation amount of $-26.2 \%$. The amount of adjusted $\mathrm{R}$ square of $2.8 \%$ explains a very weak correlation in advance. Nonetheless, the correlation is considered as significant by the $t$ value located outside the range of lower and upper limits.

The main reason explaining this result is the uncertainty the smaller-sized companies have, which causes a higher risk such as not being able to cover all liabilities because the limited sources it has nor pay dividends when equity is diminished. Nevertheless, risk is sometimes just risk and when the risk is not yet to happen, the company's willingness to pay the investors in return is much bigger than the company with low level of risk. Therefore, a higher return is easier to earn when investing in smaller companies which is the main consideration for the investors.

Another analysis is related to the prices and the distribution of dividends. The bigger the size of a company even though its share price tends to be more stable compared to the smaller-size companies, the amount of dividends distributed is much less than the smaller companies. The purpose of this is to keep its retained earnings to buy capitalized assets and for operations.

\section{Multiple Regression Analysis}

After the independent variables (current ratio, debt-to-equity, total asset turnover, price-to-earnings ratio, and firm size) were tested individually against the dependent variable (stock return) using simple regression model in hypothesis testing, now the combination of all independent variables against stock return is tested using multiple regression analysis using SPSS. The F-Test is also conducted using ANOVA, and so is the model summary of all variables. The results generated are as follows:

All of the taken values are then used to establish this following multiple linear equation:

$y=a+b . x 1+c . x 2+d . x 3+e . x 4+$ f.x 5

$\mathrm{y}=-1.657+0.307 \mathrm{x} 1+1.426 \mathrm{x} 2+$ $0.267 \times 3-0.001 \times 4-4,46 \mathrm{E}-12 \times 5$

where :

$\mathrm{y}$ is stock return; $\mathrm{x} 1$ is current ratio; $\mathrm{x} 2$ is debt-to-equity ratio; $\mathrm{x} 3$ is total asset turnover; $\mathrm{x} 4$ is price-to-earnings ratio; $\mathrm{x} 5$ is firm size; $\mathrm{b}, \mathrm{c}, \mathrm{d}, \mathrm{e}$, and $\mathrm{f}$ are the constants of " $\mathrm{B}$ " for each variable; and $\mathrm{E}$ represents the notation of $10 \mathrm{n}$. 
The significance level of 0.065 for F-Test gives an interpretation of a insignificant relationship between the predictors $(\mathrm{CR}$, DER, TATO, P/E, and firm size) and the dependent variable (stock return) since the value is $>0.05$.

The amount of model generated is 1 since the main goal of the model fit is to find the the ability of 5 predictors (CR, DER, TATO, P/E, and firm size) to justify the amount of dependent variable (stock return). As shown above, the correlation of all 5 independent variables towards stock return is 0.631 or $6.31 \%$ represented by the "R". The amount of "R Square" in this model is 0.399 while the "Adjusted R Square" is 0.241 or only $2,41 \%$, which means those ratios: current ratio, debt-toequity ratio, total asset turnover, price-toearnings ratio, and firm size if combined as one are not reliable to forecast the stock return.

Based on one-one-one correlation, for current ratio, there is a negative and significant correlation towards stock return caused generally by the increase in current liabilities that occurs similarly in the 5 companies due to their operating activities which cause the CR decrease over the years while the stock return increase. As for the debt-to-equity ratio, there is a positive and significant correlation towards stock return described by the facts that not only the current liabilities of the 5 companies become higher, but also their long-term liabilities due to expansion and any funding necessity which then affects the higher amount of total debts. The positive correlation between total asset turnover and stock return is mostly initiated by the increase sales volume and pricing as the business strategy done by each company which cause the TATO to rise as well as the stock return, since the increasing revenues do attract the investors. The correlation between price-to-earnings ratio and stock return however is negative and insignificant basically because $\mathrm{P} / \mathrm{E}$ ratio does not talk about the dividends paid while dividends are the important part of computing stock return. Lastly between firm size and stock return is negative and significant since the dividends paid by the bigger size of companies is less than the ones paid by the smaller-sized companies. The purpose is to save the cash on hand for recapitalization to be used for next operating activities.

The supporting reasons that can explain this condition is that investors tend to look at how well the company is operating and how able the company can give a guarantee that they can get return as much as possible, which is not sufficient if it is only represented by the ratios used in this thesis. The ratios of profitability such as return on asset (ROA) and return on equity (ROE) are widely used to observe the company's performance. The better the performance, the more it is able to pay dividends which then attract the investors. Thus, the addition of other ratios is suggested rather than only using these ratios to predict the stock return.

\section{CONCLUSIONS}

1. The current ratio has a negative and significant correlation towards stock return. According to statistical tools used in this study, the result is insignificant since current ratio only has -0.036 or $-3.6 \%$ correlation towards stock return. The correlation of $3.6 \%$ is below $10 \%$, indicating that it is a very weak correlation. However coping with the economic condition in Indonesia during 2010-2014 such as the compliance with the new law and the alteration of consumer behaviour during the period has led to a major 
attention paid to cash, receivables, and other accounts that can be liquidated to pay their loans quickly.

2. The debt-to-equity ratio is proven to have a positive and significant correlation towards stock return although the statistics portrays a result of 0.064 or $6.4 \%$ correlation between debt-to-equity ratio and the stock return. Because $6.4 \%$ is below $10 \%$, the correlation is categorized as trivial. However, the consideration of phenomenon of inflation rate, building new projects, and improvement, which affect the amount of both short- and longterm payables. Thus, the relationship becomes significant.

3. The total asset turnover is positively related to the stock return and it is significant. The percentage of correlation is 1.5 . The amount of below $10 \%$ indicates a very weak correlation. However, because there are sufficient sources informing about the strategy done by the most companies in food and beverage industry which is raising the sales volume or price to survive the global competition and it significantly impacts the rise in stock return.

4. The price-to-earnings ratio has a negative and insignificant correlation towards stock return. The coefficient shows a -0.029 correlation or $-2.9 \%$, which under statistics, is also very weak. It is explained by the blur determination of price and earnings if both factors when collaborate, can be effective to be used to analyze the profitability of companies in this industry. It cannot also be claimed as ineffective as well because this ratio can only be used for a specific industry instead of between different industries.

5. The result to have a negative and significantcorrelation towards stock return. The correlation is 0.028 or $2.8 \%$ which is a very weak one. This is caused by the uncertainty of smaller-sized companies in developing countries like Indonesia which brings the business into a higher level of risk. The uncertain accounting methods and amateur accounting system can lead to higher risks. However, the investors in Indonesia seem to have tendency of getting more return than less return but more stable financial movement. It then seconds the principle of high risk - high return in corporate finance.

\section{V.II. Recommendations}

Related to the conclusion in previous section, some hints are suggested as follows:

1. The current ratio, debt-to-equity ratio, total asset turnover, and firm size as investigated, are believed to be such reliable factors to determine the stock return in the Indonesia stock market. The ability of the companies to get the aid to fulfill its liabilities as soon as possible is important when company is in an urgent condition. It is also important to see the ability of the company in generating sales, since it contributes a lot to its net income, which represents the profitability in front of various users. In developing countries like Indonesia, there are still numerous incidents and cases related to debts, manipulation, frauds, and bankruptcy, so it needs an extra attention of assets, liabilities, and equity that are related to payment issues, no matter it is small or big companies.

2. For companies, it is recommended to keep its liquidity in a good condition to avoid the operations being disrupted during sudden crisis so that it can maintain the reliance from the investors. A good condition in this case simply means a condition where company's current liabilities do not excess its current assets. 
However, the company should also ensure that it is not liquid because it may reduce the profitability of the company.

3. Investors should not depend fully on the ratios used in this study. Other ratios such as earnings per share, profit margin, or others should also be considered since the main attraction of the investors in Indonesia is the profit they can earn.

4. The research regarding the accounting information towards stock return should be done between industries to compare which industry is the best for investors to invest their money in.

5. The significance result of ratios towards stock return should not entirely rely on the statistical results. The statistic is only a tool to assist the process of quantified data of different indicators. The macro and microeconomic factors should also be considered in determining the significance of one variable.

6. Since there is still so many differences in results found in studies done by the different researchers, the examination concerning these ratios is recommended to be conducted by next researchers.

\section{REFERENCES}

Amir, A. Z. (2011). European Financial Management. The return of the size anomaly: Evidence from the german stock market.

Babaei, A., Babaei, M., Abdi, H., \& Rezaei, M. (2014). Evaluation the principal components of accounting and its impact on the stock returns of listed companies in Tehran Stock Exchange.

BKPM. (2014). Investing in Indonesia's
Food \& Beverage Industry. An overview of opportunities, capabilities and provisions.

Bodie, Z., Kane, A., \& Marcus, A. J. (2013). Investments and Portfolio Management. McGraw-Hill.

Brealey, Myers, \& Allen. (2011). Principles of Corporate Finance. New York: McGraw-Hill.

Bühler, W., Hax, H., \& Schmidt, R. (2012). Empirical Research on the German Capital Market. Heidelberg: SpringerVerlag Berlin Heidelberg.

Damayanti, D. (2013). Industry Update PT Bank Mandiri (Persero) Tbk. 2.

Drake, P. P., \& Fabozzi, F. J. (2012). Analysis of Financial Statements: 3rd Edition. John Wiley \& Sons.

Drake, P. P., \& Fabozzi, J. F. (2010). The Basics of Finance: An Introduction to Financial Markets, Business Finance, and Portfolio Management. John Wiley \& Sons.

Drake, S. M., \& Dingler, R. G. (2001). The Practical Guide to Finance and Accounting.

Dyck, J., Woolverton, A. E., \& Rangkuti, F. Y. (2012). Indonesia's Modern Food Retail Sector:. Interaction with Changing Food Consumption and Trade Patterns.

Emerald. (2015). Common Stock vs. Preferred Stock. Retrieved 2015, from Financial Services of America, Inc. Web site: www.fsal.com

Er, Ş., \& Vuran, B. (2012). Factors Affeting Stock Returns of Firms Quoted in ISE Market: A Dynamic Panel Data Approach.

Folger, J. (2014). How are share prices set? Retrieved 2014

Frank, R. H., Bernanke, B. S., Gan, L. 
L., \& Kang, C. (2009). Principles of Economics. New York: McGraw-Hill.

Gerbens-Leenes, P. W., Nonhebel, S., \& Krol, M. S. (2010). Food consumption patterns and economic growth. Increasing affluence and the use of natural resources.

Ghasempour, A., \& Ghasempour, M. (2013). The Relationship between Operational Financial Ratios and Firm's Abnormal Stock Returns.

Hasintongan, R. R. (2010). ANALYSIS OF THE INFLUENCE OF ACCOUNTING VARIABLES ON STOCK RETURNS.

IAS. (2011). Retrieved from http:// ec.europa.eu/internal_market/accounting/ docs/consolidated/ias1_en.pdf

Kantrovich, A. J. (2011, December 16). Financial Ratios Part 17 of 21: Asset Turnover Rate | MSU Extension. Retrieved from http://msue.anr.msu.edu

Larson, K. D., Wild, J. J., \& Chiappetta, B. (2013). Fundamental Accounting Principles - 17th Edition. McGraw-Hill.

Latham, J. R. (2000). There's enough food for everyone, but the poor can't afford to buy it. Nature, pp. 404, 222.

Leledakis, G., Davidson, I., \& Smith, J. (2004). Does Firm Size Predict Stock Returns? Evidence from London Stock Exchange.

Martani, D., Mulyono, \& Khairurizka, R. (2009). The Effects of Financial Ratios, Firm Size, and Cash Flow from Operating Activities in the Interim Report to the Stock Return.

Pietersz, G. (2005-2013). Valuation ratios - Valuation - Moneyterms: investment definitions and explanations. Retrieved March 22, 2015, from http://moneyterms. co.uk/valuation-ratios/
Poznanski, J., Sadownik, B., \& Gannitsos, I. (2013, December). FINANCIALRATIO ANALYSIS - Financial Ratio Analysis Dec 2013.pdf. Retrieved March 2015, from http://www.demonstratingvalue. org/sites/default/files/resource-files/ Financial\%20Ratio\%20Analysis \%20 Dec\%202013.pdf

Ross, S. A., Westerfield, R. W., \& Jordan, B. D. (2010). Corporate Finance Fundamentals. New York: McGraw-Hill.

Subramanyam, K. R., \& Wild, J. J. (2012). Financial Statement Analysis. McGrawHill.

Tamaki, R. (2013). The Future of the Asian Economic.

Tantipanichkul, P., \& Supattarakul, S. (2011). Can Historical Accounting Information Be Used to Predict Future Stock Returns?

Warr, P. (2011). Working Papers in Trade and Development. Food Security vs. Food Self-Sufficiency: The Indonesian Case.

Weygandt, J. J., Kimmel, P. D., \& Kieso, D. E. (2010). Accounting Principles.

Wild, J. J., Shaw, K. W., \& Chiapetta, B. (2012). Principles of Accounting - 19th Edition. McGraw-Hill.

Williams, J. R., Haka, S. F., Bettner, M. S., Carcello, J. V., Lam, N. C., \& Lau, P. T. (2011). Financial Accounting including International Financial Reporting Standards (IFRS). McGrawHill.

Zhang, G. (2013). Accounting Information and Equity Valuation: Theory, Evidence, and Applications. New York: Springer. 